\title{
Evaluating the properties of cellular ceramics prepared with a granite dust and plantain (Musa paradisiaca) peel powder for external wall thermal insulation of buildings
}

\author{
P.O.Odewole ${ }^{1 *}$ \\ ${ }^{1}$ Federal University of Technology, Akure, Ondo State, Nigeria
}

\begin{abstract}
The viability of preparing cellular ceramics suitable for external wall insulation of buildings was investigated using granite dust, ball clay, plantain peels, sodium silicate, and sodium hydroxide. The predetermined compositions of the raw materials were mixed homogeneously and then subjected to uniaxial pressing at $10 \mathrm{MPa}$. The formulated samples were oven-dried and sintered in a gas kiln at $850^{\circ} \mathrm{C}$ for $3 \mathrm{~h}$. The obtained cellular ceramics were then subjected to standard property tests. The results revealed water absorption of $19.5-41.7 \%$, bulk density of $1.39-1.86 \mathrm{~g} / \mathrm{cm}^{3}$, apparent porosity of $36.4-66.7 \%$, thermal conductivity of $0.09-0.62$ $\mathrm{W} /(\mathrm{m} . \mathrm{K})$, and compressive strength of 0.9-18.4 MPa. From the results, the optimum sample of the cellular ceramics prepared is a potential thermal insulation material for load-bearing applications such as walling systems in buildings, where not only low thermal conductivity but also high mechanical strength is required.
\end{abstract}

Keywords: cellular ceramics, wastes utilization, external wall thermal insulation.

\section{INTRODUCTION}

Energy consumption in buildings is enormous and is expected to further increase due to improving standards of living globally and the increasing rate of the world population. Among four main sectors [industrial, building (residential/commercial), transportation, and agricultural] where global energy consumption is distributed, the building sector happens to be the highest energy consumer [1]. Current environmental issues require intensive research on energy efficiency and energy savings in buildings to reduce consumption of conventional fuel and $\mathrm{CO}_{2}$ emissions [2]. Given the global concern to reduce carbon emission and energy bills, thermal insulation is an important technology to reduce energy consumption in buildings. Insulating the building envelope is the most important of all energy conservation measures due to the fact that it has the greatest impact on energy expenditure [3]. Thermal insulation prevents heat gain and loss through the building envelope and at the same time reducing carbon emission which results from cooling buildings using mechanical and electrical driven devices such as air-conditioners and fans. Since heat transfer in buildings can be through conduction, convection, or radiation, thermal insulators help to control these various forms of heat transfer. One of the most effective possibilities to improve the energy efficiency of buildings is to reduce heat loss through the building envelope by internal or external wall insulation [2]. It is of utmost importance to improve the thermal performance of the building envelope, especially

*peterodewole@gmail.com

Dhttps://orcid.org/0000-0002-0977-2993 the wall body, with the purpose of creating a high comfort level for the occupants and decreasing the building energy consumption since heat transfer loss in building envelopes accounts for about $60-80 \%$ of the total heat transfer loss [4]. Thermal insulation is one of the simplest, most effective, and most economical methods to optimize energy use and prevent energy waste in residential buildings $[5,6]$.

Based on a model used in studying 50 buildings in Irbid area, Jordan, Alshorman and Alshorman [7] discovered that wall insulation was the most effective method for energy saving, accounting for $63.11 \%$ of energy-saving while solar photovoltaic panels account for $14.11 \%$ of energy saving, using double glazed windows accounts for $7.26 \%$ of energy saving, and using LED light bulbs, windows overhanging, and light color stones take $6.89 \%, 5.14 \%$, and $3.46 \%$ of energy saving, respectively. Based on the result of research on the cost-effectiveness of thermal wall systems for residential housing, Saha [8] revealed that a 79\% cost saving was achieved in heating and cooling when a noninsulated wall was compared to an insulated wall in a hotter climate. It is noteworthy that external wall insulation is a green and energy-saving project that can greatly improve the thermal performance of buildings [4, 9]. Through external wall insulation, the building can also benefit from aesthetic improvement besides improving the thermal comfort as well as reduced disturbance of the occupants, the disappearance of mold, and reduced maintenance [2]. Given that the interior insulation is more suitable for the intermittent cooling operation, while the exterior insulation is more suitable for the cooling continuous operation [4], the external wall insulation should therefore be given more important consideration in buildings. 
Among other available alternatives, using porous materials for improving the energy efficiency in buildings has received significant attention [10]. Cellular or porous materials include a solid matrix with interconnected pores and they are of significant scientific and technological interest for energy conversion and conservation [10]. Cellular ceramics are a key material suitable for thermal insulation of buildings due to its high surface area and permeability, low density and specific heat, high thermal and acoustic insulation, and high chemical resistance in addition to the fact that it is non-flammable and flame resistant, chemically inert, and non-toxic. Different processing techniques of cellular ceramics include gel casting, replication of a sacrificial foam template, direct foaming of a liquid slurry, burn-out of fugitive pore formers, among others [11, 12]. Andreola et al. [13] experimented three different manufacturing techniques of porous ceramics and concluded that one technique can be preferable as compared to the others depending on the specific use. The pore-former technique is based on the mixing of the ceramic powder, or its precursors, with a fugitive material that acts as a poreforming agent, followed by the formation of a green body, extraction of the pore-former, and sintering of the ceramic phase [14]. The burning out of pore-former's technique is widely used given its easy usability for achieving optimum results [15].

The utilization of cheap materials as pore-generating agents can facilitate the production of low-cost porous ceramics [16]. In this regard, Odewole and Folorunso [17] obtained porous ceramic from granite dust, clay, and sawdust and then suggested further research to evaluate the effectiveness of other organic additives. Generally, the use of agro-wastes and biomass such as spent coffee grounds [18, 19], wheat straw and sunflower [20], rice husks [21, 22], and many others as a pore-forming agent in the development of porous ceramics tends towards environmental sustainability. Hence, plantain peel powder was used as the pore-forming agent in this study. The use of cellulosic wastes such as plantain peels as a pore-forming agent has a number of advantages including easy availability and processing (narrow decomposition temperature range of 300-350 ${ }^{\circ} \mathrm{C}$ ) and low-cost [23]. Plantain (Musa paradisiaca) is a major group of banana varieties (genus Musa) that are stapled foods in many tropical areas including Western and Central Africa, representing the world's second-largest fruit crop with an annual production of 129,906,098 metric tons [24]. Aside from the extensive use of the Musa species' peels as a vital nutrient source in the formulation of animal feeds and soap production [25], the viability of banana leaves and banana peels as pore-forming agents in the production of cellular material for thermal insulation has been experimented [26, 27]. Cornejo et al. [28] revealed that organic wastes such as banana peels contain valuable minerals that can serve as raw materials for the production of glass and ceramics.

Intensifying mining and mineral processing such as in granite quarrying is important to modern-day development in the building and construction sector. However, it is associated with the accumulation of significant amounts of waste and pollution of the environment since only about 45$50 \%$ of the total amount of the mined and processed minerals are used as aggregate (crushed stone), while other products in the form of mining waste are placed in a mining dumps [29]. In this regard, one major way to tackle the problem of waste generation associated with quarries is to devise technological solutions that ensure the efficient utilization of industrial wastes for the production of useful products for various important purposes. While granite dust has been extensively used as fine additives in concrete production $[30,31]$, research works based on its utilization for the preparation of cellular ceramics are still scarce. Furthermore, chemical-aided sintering of cellular ceramics is a costeffective technique that needs to be grossly explored. This is due to the fact that it makes the development of cellular ceramics from naturally occurring rocks possible through a single-step rather than the conventional two-step sintering, which is a more cost-and-energy demanding route [32]. While developed countries have made significant efforts in establishing standard building energy codes (BECs) often accompanied by the enforced use of thermal insulation in buildings, developing countries such as Nigeria, seem to have done very little in this area. In developing countries, particularly in Nigeria, the government's effort towards the construction of residential and commercial buildings is still considerably inadequate [33]. Given that this laxity is mostly covered up by individuals in the bid to own their personal houses, stringent building standards are scarcely followed. In this sense, the perceived high cost of thermal insulating materials is a significant limiting factor to the substantial implementation of energy-efficient building policy in developing countries such as Nigeria [34]. In this regard, value-added ceramic building materials such as meet the need for low-cost thermal insulation of buildings can be obtained through waste valorization. The aim of this research is to develop cellular ceramics from waste resources including granite dust and plantain peels for use in external wall insulation with a view to providing environments that promote the use of sustainable materials, as well as energy-efficient buildings.

\section{MATERIALS AND METHODS}

The materials used include granite dust, plantain peel powder (PPP), ball clay, sodium hydroxide $(\mathrm{NaOH})$, and sodium silicate $\left(\mathrm{Na}_{2} \mathrm{SiO}_{3}\right)$. Granite dust served as the base raw material. Ball clay served as the binder. Plantain peels served as the pore-forming agent. Sodium hydroxide and sodium silicate served as the sintering aid to facilitate single-step sintering of the cellular ceramics. Granite dust was sourced from Dotmond Quarry, Ita-Ogbolu, Ondo State, Nigeria. Ball clay was sourced from Ire-Ekiti, Ekiti State, Nigeria, and plantain peels were obtained from the Seed Department, Agricultural Development and Processing, Akure, Nigeria. The sodium silicate used was supplied 
Table I - Chemical compositions of the raw materials used.

\begin{tabular}{cccc}
\hline Oxide & $\begin{array}{c}\text { Plantain peel } \\
\text { powder (PPP) }\end{array}$ & $\begin{array}{c}\text { Granite } \\
\text { dust }\end{array}$ & $\begin{array}{c}\text { Ball } \\
\text { clay }\end{array}$ \\
\hline $\mathrm{Al}_{2} \mathrm{O}_{3}$ & 5.88 & 12.82 & 21.60 \\
$\mathrm{SiO}_{2}$ & 7.18 & 59.72 & 58.15 \\
$\mathrm{P}_{2} \mathrm{O}_{5}$ & 3.37 & 0.44 & 0.21 \\
$\mathrm{SO}_{3}$ & 10.96 & 0.82 & 0.71 \\
$\mathrm{~K}_{2} \mathrm{O}$ & 43.73 & 5.74 & 2.30 \\
$\mathrm{CaO}$ & 8.43 & 5.67 & 0.15 \\
$\mathrm{TiO}_{2}$ & - & 0.35 & 1.81 \\
$\mathrm{Fe}_{2} \mathrm{O}_{3}$ & 5.10 & 11.29 & 12.10 \\
$\mathrm{ZnO}$ & 0.57 & - & - \\
$\mathrm{SnO}_{2}$ & 6.39 & 1.14 & - \\
$\mathrm{Sb}_{2} \mathrm{O}_{3}$ & 5.94 & 1.10 & - \\
$\mathrm{LOI}$ & 2.25 & 0.73 & 2.57 \\
\hline
\end{tabular}

by Qualikems Fine Chemicals and contained about $12 \%$ $\mathrm{Na}_{2} \mathrm{O}, 30 \% \mathrm{SiO}_{2}$, and $58 \%$ water. The sodium hydroxide pellets used were supplied by May \& Baker, Dagenham, England, and had a minimum assay of $98.9 \%$. The chemical composition of the locally sourced raw materials used was obtained from X-ray fluorescence (XRF) analysis carried out using a spectrometer (EDX3600B, Skyray Instr.). $\mathrm{X}$-ray diffraction (XRD) pattern of the optimum sample of the produced cellular ceramics was obtained using a diffractometer [binary V4 X-ray $(\theta / 2 \theta$ system), Bruker] equipped with $\mathrm{CuK} \alpha$ radiation $(\lambda=1.54060 \AA)$, measured at $25^{\circ} \mathrm{C}$, operating at $10 \mathrm{~mA}, 30 \mathrm{kV}$, in the $2 \theta$ range from $5-90^{\circ}$ with $0.026^{\circ}$ step size and $56.52 \mathrm{~s}$ scanning time. The raw data obtained were processed with software (X'Pert HighScore, PANalytical). Microstructural properties of the developed cellular ceramics fired at $850{ }^{\circ} \mathrm{C}$ were investigated using a stereomicroscope (SMZ745T, Nikon). The chemical compositions of the raw materials used are shown in Table I.

Granite dust, ball clay, and plantain peels were separately sun-dried and ground using a grinding machine. Each of these materials was then sieved. Granite dust and ball clay were sieved through a $300 \mu \mathrm{m}$ British standard sieve while plantain peel powder was sieved through a $425 \mu \mathrm{m}$ British standard sieve. In order to enhance the compaction of granite dust, being a non-plastic material, the addition of $50 \%$ ball clay to granite dust was found suitable. The mixture of $100 \%$ granite dust and $50 \%$ ball clay, designated as $\mathrm{GrC}$ constituted the starting material. $40 \% \mathrm{NaOH}$ solution was prepared by diluting $400 \mathrm{~cm}^{3}$ of $\mathrm{NaOH}$ pellet in $1000 \mathrm{~cm}^{3}$ of water. Formulation of samples was done using varying weight fractions of $\mathrm{GrC}$ (85-95\%) and PPP (5-15\%) mixed with a constant weight fraction of sodium hydroxide+sodium silicate in three different amounts $(7.5 \%, 10 \%$, and $12.5 \%$ of each of the reagents) as shown in Table II. The formulated samples were thoroughly mixed. Each of the homogenized compositions was poured

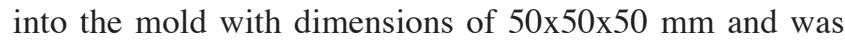
subjected to uniaxial pressing at $10 \mathrm{MPa}$. The samples were dried in an electric oven at $110^{\circ} \mathrm{C}$ for $6 \mathrm{~h}$ and then sintered in a gas kiln at $850^{\circ} \mathrm{C}$ for $3 \mathrm{~h}$.

Physical, mechanical, and thermal properties tests: after sintering, property tests were carried out on the sintered samples of cellular ceramics to obtain their values of water absorption, bulk density, apparent porosity, compressive strength, and thermal conductivity at room temperature. Water absorption, bulk density, and apparent porosity: the weight of the sintered sample $\left(\mathrm{W}_{1}\right)$ was taken. The sample was then soaked in boiling water for $3 \mathrm{~h}$ and the weight of the soaked sample $\left(\mathrm{W}_{2}\right)$ was taken. The sample was suspended in water using a spring balance and the suspended weight of the sample $\left(\mathrm{W}_{3}\right)$ was taken. Water absorption, bulk density, and apparent porosity measurements were carried out on the sintered samples according to the ASTM C20-00 standard [35]. Water absorption (Wa), bulk density $\left(\varrho_{\mathrm{b}}\right)$, and apparent porosity (Ap) were calculated, respectively, by:

Table II - Formulation of cellular ceramic samples from the raw materials.

\begin{tabular}{ccccccc}
\hline $\begin{array}{c}\text { Sample } \\
\text { grouping }\end{array}$ & $\begin{array}{c}\text { Sample } \\
\text { designation }\end{array}$ & Sample formulation & $\begin{array}{c}\mathrm{GrC} \\
(\mathrm{g})\end{array}$ & $\begin{array}{c}\mathrm{PPP} \\
(\mathrm{g})\end{array}$ & $\begin{array}{c}\mathrm{Na}_{2} \mathrm{SiO}_{3} \\
\left(\mathrm{~cm}^{3}\right)\end{array}$ & $\begin{array}{c}\mathrm{NaOH}^{3} \\
\left(\mathrm{~cm}^{3}\right)\end{array}$ \\
\hline \multirow{2}{*}{1} & $\mathrm{P}_{1}$ & $95 \% \mathrm{GrC}+5 \% \mathrm{PPP}+7.5 \% \mathrm{Na}_{2} \mathrm{SiO}_{3}+7.5 \% \mathrm{NaOH}$ & 95 & 5 & 7.5 & 7.5 \\
& $\mathrm{P}_{2}$ & $90 \% \mathrm{GrC}+10 \% \mathrm{PPP}+7.5 \% \mathrm{Na}_{2} \mathrm{SiO}_{3}+7.5 \% \mathrm{NaOH}$ & 90 & 10 & 7.5 & 7.5 \\
& $\mathrm{P}_{3}$ & $85 \% \mathrm{GrC}+15 \% \mathrm{PPP}+7.5 \% \mathrm{Na}_{2} \mathrm{SiO}_{3}+7.5 \% \mathrm{NaOH}$ & 85 & 15 & 7.5 & 7.5 \\
& $\mathrm{~L}_{1}$ & $95 \% \mathrm{GrC}+5 \% \mathrm{PPP}+10 \% \mathrm{Na}_{2} \mathrm{SiO}_{3}+10 \% \mathrm{NaOH}$ & 95 & 5 & 10.0 & 10.0 \\
2 & $\mathrm{~L}_{2}$ & $90 \% \mathrm{GrC}+10 \% \mathrm{PPP}+10 \% \mathrm{Na}_{2} \mathrm{SiO}_{3}+10 \% \mathrm{NaOH}$ & 90 & 10 & 10.0 & 10.0 \\
& $\mathrm{~L}_{3}$ & $85 \% \mathrm{GrC}+15 \% \mathrm{PPP}+10 \% \mathrm{Na}_{2} \mathrm{SiO}_{3}+10 \% \mathrm{NaOH}$ & 85 & 15 & 10.0 & 10.0 \\
& $\mathrm{~T}_{1}$ & $95 \% \mathrm{GrC}+5 \% \mathrm{PPP}+12.5 \% \mathrm{Na}_{2} \mathrm{SiO}_{3}+12.5 \% \mathrm{NaOH}$ & 95 & 5 & 12.5 & 12.5 \\
& $\mathrm{~T}_{2}$ & $90 \% \mathrm{GrC}+10 \% \mathrm{PPP}+12.5 \% \mathrm{Na}_{2} \mathrm{SiO}_{3}+12.5 \% \mathrm{NaOH}$ & 90 & 10 & 12.5 & 12.5 \\
& $\mathrm{~T}_{3}$ & $85 \% \mathrm{GrC}+15 \% \mathrm{PPP}+12.5 \% \mathrm{Na}_{2} \mathrm{SiO}_{3}+12.5 \% \mathrm{NaOH}$ & 85 & 15 & 12.5 & 12.5 \\
\hline
\end{tabular}




$$
\begin{aligned}
& \mathrm{Wa}=\left(\mathrm{W}_{2}-\mathrm{W}_{1}\right) / \mathrm{W}_{1} \cdot 100 \\
& \mathrm{Q}_{\mathrm{b}}=\mathrm{W}_{1} \cdot \mathrm{Q}_{\mathrm{w}} /\left(\mathrm{W}_{2}-\mathrm{W}_{3}\right) \\
& \mathrm{Ap}=\left(\mathrm{W}_{2}-\mathrm{W}_{1}\right) /\left(\mathrm{W}_{2}-\mathrm{W}_{3}\right)
\end{aligned}
$$

where $\varrho_{w}$ is the density of water. Compressive strength: compressive strength test was carried out on the produced samples of cellular ceramics with the aid of a mechanical testing machine (series 3369, Instron) at a fixed crosshead speed of $10 \mathrm{~mm} \cdot \mathrm{min}^{-1}$ in accordance with ASTM C240-97 standard [36]. The compressive strength of the sample $\left(\sigma_{c}\right.$, $\mathrm{MPa})$ was calculated by:

$$
\sigma_{\mathrm{c}}=\mathrm{L} / \mathrm{A}
$$

where $\mathrm{L}$ is the applied load on the sample to fracture $(\mathrm{kN})$, and A is the cross-sectional area of the sample $\left(\mathrm{mm}^{2}\right)$.

Thermal conductivity: the area (A) and thickness ( $\delta$ ) of each of the samples was recorded. Each sample was fixed between two copper discs provided within the equipment set up.A conical flask containing $50 \mathrm{~mL}$ of water was placed directly above and in contact with the sample. A thermometer passed through the cork of the conical flask to read the initial temperature $\left(\mathrm{T}_{1}\right)$ of the water in the flask. The test section was then closed and the initial temperature of water in the conical flask was noted. A second thermometer was inserted into the steam outlet pipe offset to monitor the steam temperature so as to ensure a constant base temperature of $100{ }^{\circ} \mathrm{C}(\mathrm{Ts}) .5 \mathrm{~L}$ of water was measured and poured into the boiler and it was ensured that the steam inlet valve, outlet valve, and condensate outlet valve were all closed. With the boiler cover remaining opened, the boiler was switched on. The boiler cover was closed immediately after the water started boiling and the steam inlet valve was fully opened while all the remaining valves were closed. Immediately the steam inlet valve was opened, the time reading $(\tau)$ commenced with the aid of a stopwatch. The experiment was timed in each case for $10 \mathrm{~min}$ and the final temperature $\left(\mathrm{T}_{2}\right)$ of the water in the conical flask was noted at the end of the fixed time. At the end of each experiment, the steam outlet valve was opened to release steam. The remaining samples were also subjected to the same experimental procedure as described above and the water in the boiler was refilled to maintain $5 \mathrm{~L}$ in each case. The experiment was repeated twice for each of the test samples of cellular ceramics and a mean temperature value was obtained. The value of the thermal conductivity $\left[\mathrm{k}, \mathrm{W} /\left(\mathrm{m} .{ }^{\circ} \mathrm{C}\right)\right]$ for each of the samples was determined by $[37,38]$ :

$$
\mathrm{k}=2.303 \mathrm{M} . \mathrm{C} . \delta .\left[\log \left(\theta_{1} / \theta_{2}\right) /(\mathrm{A} . \tau)\right]
$$

where, $\mathrm{M}$ is the mass of water in the conical flask $(\mathrm{kg}), \mathrm{C}$ the specific heat capacity of water in conical flask $\left[4200 \mathrm{~J} /\left(\mathrm{kg} .{ }^{\circ} \mathrm{C}\right)\right]$, $\delta$ the thickness of the sample (m), $\theta_{1}=\mathrm{Ts}-\mathrm{T}_{1}$ and $\theta_{2}=\mathrm{Ts}-\mathrm{T}_{2}$, Ts the temperature of steam $\left({ }^{\circ} \mathrm{C}\right), \mathrm{T}_{1}$ the initial temperature of water in the conical flask $\left({ }^{\circ} \mathrm{C}\right), \mathrm{T}_{2}$ the final temperature of water in the conical flask $\left({ }^{\circ} \mathrm{C}\right)$, A the area of the sample $\left(\mathrm{m}^{2}\right)$, and $\tau$ is the time (s).

\section{RESULTS AND DISCUSSION}

Sintering behavior: varying properties were observed in the resulting sintered samples of cellular ceramics and these properties were observed to have been influenced by the amount of plantain peel powder (pore-forming agent) added and the amount of chemical reagents $(\mathrm{NaOH}$ and $\mathrm{Na}_{2} \mathrm{SiO}_{3}$ ) introduced to aid the single-step sintering of the cellular ceramics. Group 1 consisted of samples $\mathrm{P}_{1}, \mathrm{P}_{2}$, and $\mathrm{P}_{3}$ with 5\%,10\%, and 15\% PPP, respectively, and constant addition of $7.5 \% \quad \mathrm{Na}_{2} \mathrm{SiO}_{3}+7.5 \% \mathrm{NaOH}$. Group 2 consisted of samples $\mathrm{L}_{1}, \mathrm{~L}_{2}$, and $\mathrm{L}_{3}$ with $5 \%$, $10 \%$, and $15 \%$ PPP, respectively, and constant addition of $10 \% \mathrm{Na}_{2} \mathrm{SiO}_{3}+10 \% \mathrm{NaOH}$. Group 3 consisted of samples $\mathrm{T}_{1}, \mathrm{~T}_{2}$, and $\mathrm{T}_{3}$ with $5 \%, 10 \%$ and $15 \%$ PPP, respectively, and constant addition of $12.5 \% \mathrm{Na}_{2} \mathrm{SiO}_{3}+12.5 \% \mathrm{NaOH}$. Fig. 1 shows the images of the samples of cellular ceramics sintered at $850{ }^{\circ} \mathrm{C}$. From the physical appearance of the samples of the produced cellular ceramics, it was observed that the sintering aspects of the samples appeared to increase with the addition of an increasing amount of the chemical reagents used as the sintering aid.
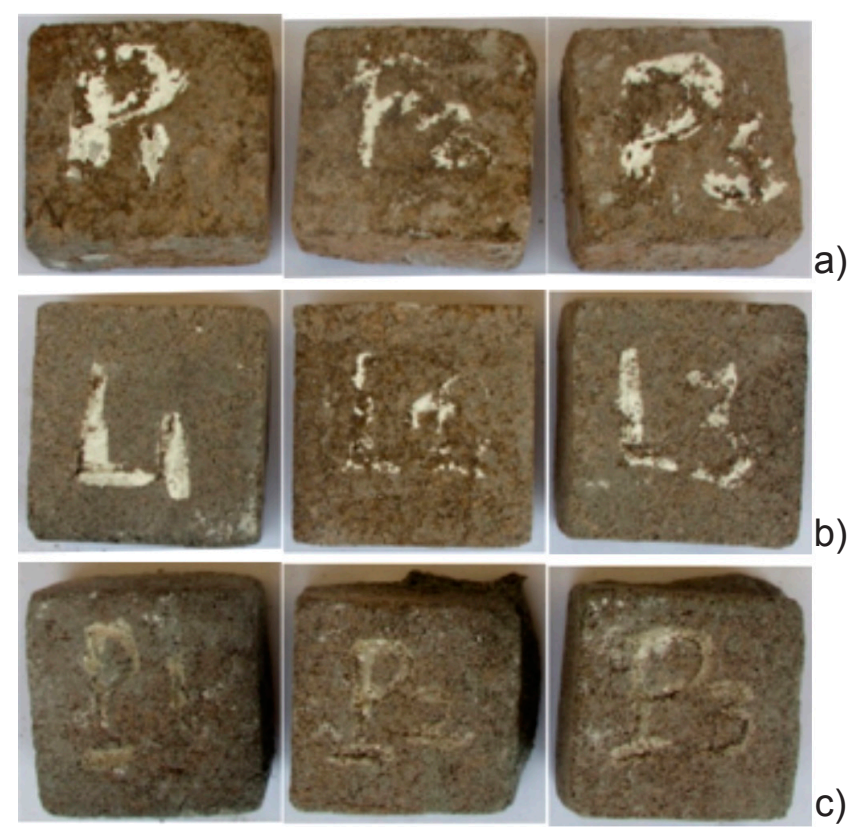

Figure 1: Images of sintered samples of: a) $95 \%, 90 \%$, and $85 \%$ $\mathrm{GrC}+5 \%, 10 \%$, and $15 \% \mathrm{PPP}+7.5 \% \mathrm{Na}_{2} \mathrm{SiO}_{3}+7.5 \% \mathrm{NaOH}$, respectively; b) $95 \%, 90 \%$, and $85 \% \mathrm{GrC}+5 \%, 10 \%$, and $15 \% \mathrm{PPP}$ $+10 \% \mathrm{Na}_{2} \mathrm{SiO}_{3}+10 \% \mathrm{NaOH}$, respectively; c) $95 \%, 90 \%$, and $85 \%$ $\mathrm{GrC}+5 \%, 10 \%$, and $15 \% \mathrm{PPP}+12.5 \% \mathrm{Na}_{2} \mathrm{SiO}_{3}+12.5 \% \mathrm{NaOH}$, respectively. Each of the sample sections: $5 \times 5 \mathrm{~cm}$.

Physical, mechanical, and thermal properties: Fig. 2 shows the effect of the addition of an increasing amount of the plantain peel powder (PPP) to a constant amount of $\mathrm{Na}_{2} \mathrm{SiO}_{3}+\mathrm{NaOH}$ (in three different groupings that is, $7.5 \%$, $10 \%$, and $12.5 \%$ of each the two reagents in each case) on the properties of the resulting cellular ceramic samples sintered at $850^{\circ} \mathrm{C}$. Figs. $2 \mathrm{a}$ and $2 \mathrm{c}$ depict that there was an increasing 
trend in the values of water absorption, corresponding with increasing values of apparent porosity in each of the samples. Figs. $2 \mathrm{~b}$ and $2 \mathrm{~d}$ show that there were decreasing values of bulk density which varied directly with a decrease in the values of compressive strength of the samples with the increasing addition of the PPP in each case. In Fig. 2e, it can be observed that since the increasing addition of PPP led to increasing porosity in each of the sample groups 1-3, this, in turn, led to the decreasing values of thermal conductivity of the samples in each case. Samples $\mathrm{P}_{1}$ and $\mathrm{T}_{3}$ had the lowest and highest values of water absorption of $19.5 \%$ and $45.2 \%$ as well as apparent porosity of $36.4 \%$ and $66.7 \%$, respectively.
Samples $\mathrm{P}_{3}$ and $\mathrm{L}_{1}$ had the lowest and highest compressive strength values of 0.9 and 18.4 MPa, respectively. Samples $\mathrm{T}_{3}$ and $\mathrm{P}_{1}$ had the lowest and highest thermal conductivity values of 0.09 and $0.62 \mathrm{~W} /(\mathrm{m} . \mathrm{K})$, respectively. This was in agreement with Ho et al. [39] that an inverse relationship exists between the thermal conductivity coefficient and porosity of the porous ceramics. The decreasing values of thermal conductivity corresponded with increasing values of water absorption as well as increasing apparent porosity in each case.

According to Zaidan et al. [40], increasing porosity that leads to low thermal conductivity does not mean getting
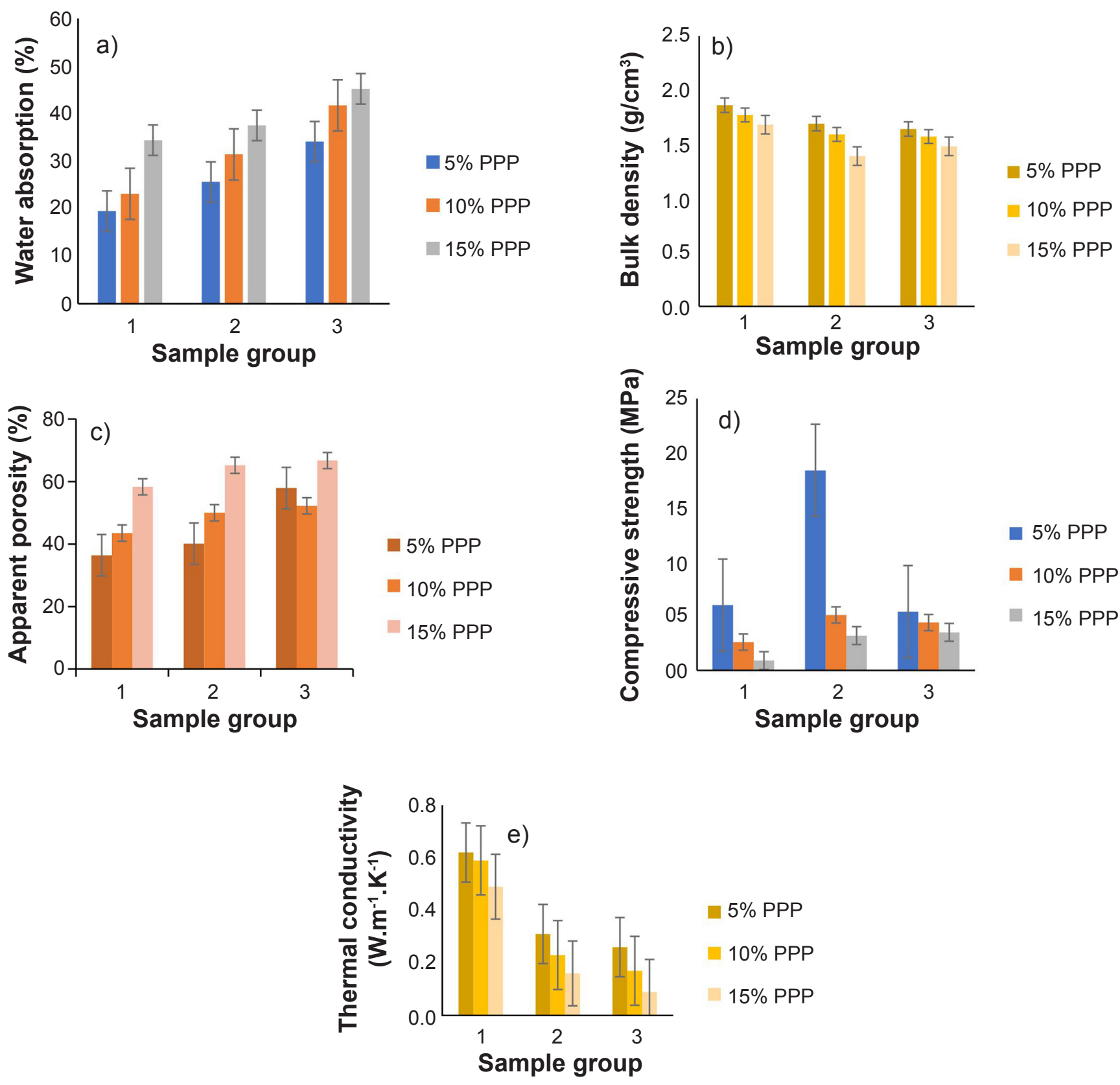

Figure 2: Results of the prepared cellular ceramics: a) water absorption; b) bulk density; c) apparent porosity; d) compressive strength; and e) thermal conductivity. 
better insulating materials, unless accompanied by good mechanical properties. Selecting porous material with lower thermal conductivity and high structural stability is important for insulation purposes [10]. This implies that low thermal conductivity, as well as high strength, should be given the utmost consideration in choosing a good thermal insulation material, most especially when used in load-bearing applications such as walling systems in buildings. Therefore, the major criteria that were considered for choosing the optimum sample were as follows: i) its thermal conductivity must not exceed the mean value of the samples; and ii) it must have the highest compressive strength among the samples that fall within the mean value of thermal conductivity. The mean thermal conductivity $\left(\lambda_{\mathrm{m}}\right)$ of the 9 samples was found to be $0.32 \mathrm{~W} /(\mathrm{m} . \mathrm{K})$. Therefore, sample $\mathrm{L}_{1}$ (consisting of $95 \% \mathrm{GrC}, 5 \% \mathrm{PPP}$, and $10 \% \mathrm{NaOH}+10 \% \mathrm{Na}_{2} \mathrm{SiO}_{3}$ ) was considered as the optimum sample for external wall insulation given that it had the highest compressive strength of $18.4 \mathrm{MPa}$ and thermal conductivity of $0.31 \mathrm{~W} /(\mathrm{m} . \mathrm{K})$. The thermo-mechanical properties of the optimum sample of cellular ceramics prepared in this study compared favorably with the optimum sample of cellular ceramics produced by Zhu et al. [41] from coal fly ash and waste glass sintered at $800{ }^{\circ} \mathrm{C}$, having thermal conductivity, compressive strength, and bulk density of $0.36 \mathrm{~W} /(\mathrm{m} . \mathrm{K}), 5.2 \mathrm{MPa}$, and $0.46 \mathrm{~g} / \mathrm{cm}^{3}$, respectively. When evaluated using EnergyPlus software, the result indicated that the optimum sample showed a good energy conservation effect for building thermal insulation materials [41]. The thermal conductivity of a material does not depend exclusively on bulk density and porosity of a material, but other characteristics such as phase composition and microstructure are also significantly important [42].

Mineralogical and microstructural behavior: Fig. 3 shows that the crystalline phases present in the optimum sample of the developed cellular ceramics sintered at $850{ }^{\circ} \mathrm{C}$ include anorthite, $\mathrm{CaAl}_{2} \mathrm{Si}_{2} \mathrm{O}_{8}$ (00-041-1486), albite, $\mathrm{NaAlSi}_{3} \mathrm{O}_{8}$ (00-019-1184), gehlenite, $\mathrm{Ca}_{2} \mathrm{Al}\left(\mathrm{AlSiO}_{7}\right)$ (00-035-0755), anorthoclase, $(\mathrm{Na}, \mathrm{K})\left(\mathrm{Si}_{3} \mathrm{Al}\right) \mathrm{O}_{8}$ (00-009-0478), microcline, $\mathrm{K}\left(\mathrm{AlSi}_{3} \mathrm{O}_{8}\right)$ (00-019-0932), and sillimanite, $\mathrm{Al}_{2} \mathrm{SiO}_{5}(00-038$ 0471). Anorthite showed the highest peak, implying that it was the main crystalline phase present in the developed cellular ceramics. The formation of anorthite and gehlenite could be a result of the transformation of $\mathrm{SiO}_{2}, \mathrm{Al}_{2} \mathrm{O}_{3}$, and $\mathrm{CaO}$ present in the raw materials used (granite, ball clay, and plantain peel powder) during heat treatment. The formation of sillimanite was a result of the reaction at high temperature between $\mathrm{SiO}_{2}$ and $\mathrm{Al}_{2} \mathrm{O}_{3}$, which were the major constituents of granite dust and ball clay used. The formation of microcline was linked to the high content of potassium oxide $\left(\mathrm{K}_{2} \mathrm{O}\right)$ contained in the plantain peel powder used. The formation of albite and anorthoclase was due to the reaction of the chemical reagents $\left(\mathrm{NaOH}\right.$ and $\mathrm{Na}_{2} \mathrm{SiO}_{3}$ ) with the main oxides present in the raw materials used, including $\mathrm{SiO}_{2}, \mathrm{Al}_{2} \mathrm{O}_{3}$, and $\mathrm{K}_{2} \mathrm{O}$ as the case may be. Some mineral phases obtained such as albite and anorthoclase were in agreement with some of the crystalline phases obtained by Mouiya et al. [27] on producing porous ceramics from clay and banana peel sintered between 900

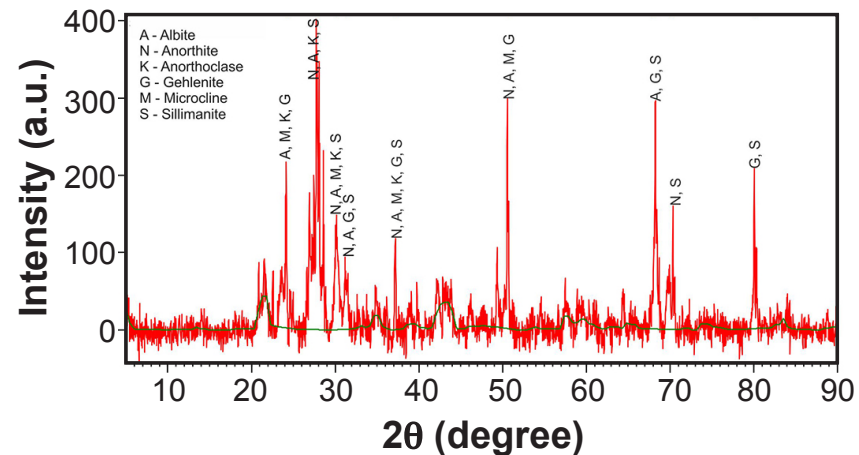

Figure 3: XRD pattern of the optimum sample of the developed cellular ceramics.

and $1100{ }^{\circ} \mathrm{C}$ while other mineral phases formed could have differed due to the effect of chemical reagents and granite dust used in this study.

Fig. 4 shows the stereomicroscope images of the developed cellular ceramics. It was observed that the pore size distribution in the samples was quite inhomogeneous and the open-celled morphology of the cellular ceramics was observable. The agglomeration and densification of the grains of the samples are represented by the lighter areas, revealing the solid phase that is typical of glassy materials. The stereomicroscope images of the samples revealed that pore size increased with the increase in contents of chemical reagents and PPP added. According to $\mathrm{Wu}$ et al. [43], the degree of open porosity and the shape and size of pores made in porous ceramics using the sintering method depend on the volume of foaming agents incorporated. Varying morphological structures showing different degrees of agglomeration and porosity were visible for each of the samples of the developed glass-ceramic foams. This
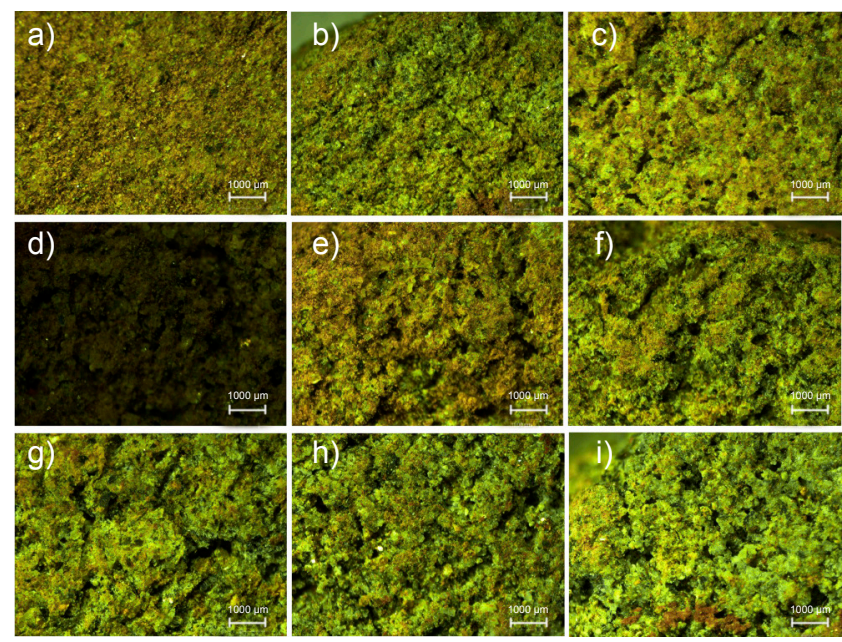

Figure 4: Stereomicroscope images of the samples: a) $95 \% \mathrm{GrC}+$ $5 \% \mathrm{PPP}+7.5 \% \mathrm{Na}_{2} \mathrm{SiO}_{3}+7.5 \% \mathrm{NaOH}$; b) $90 \% \mathrm{GrC}+10 \% \mathrm{PPP}+7.5 \%$ $\mathrm{Na}_{2} \mathrm{SiO}_{3}+7.5 \% \mathrm{NaOH}$; c) $85 \% \mathrm{GrC}+15 \% \mathrm{PPP}+7.5 \% \mathrm{Na}_{2} \mathrm{SiO}_{3}+7.5 \%$ $\mathrm{NaOH}$; d) $95 \% \mathrm{GrC}+5 \% \mathrm{PPP}+10 \% \mathrm{Na}_{2} \mathrm{SiO}_{3}+10 \% \mathrm{NaOH}$; e) $90 \% \mathrm{Gr}$ $\mathrm{C}+10 \% \mathrm{PPP}+10 \% \mathrm{Na}_{2} \mathrm{SiO}_{3}+10 \% \mathrm{NaOH} ; \quad$ f) $85 \% \mathrm{GrC}+15 \% \mathrm{PPP}+$ $\left.10 \% \mathrm{Na}_{2} \mathrm{SiO}_{3}+10 \% \mathrm{NaOH} ; \mathrm{g}\right) 95 \% \mathrm{GrC}+5 \% \mathrm{PPP}+12.5 \% \mathrm{Na}_{2} \mathrm{SiO}_{3}+$ $12.5 \% \mathrm{NaOH}$; h) $90 \% \mathrm{GrC}+10 \% \mathrm{PPP}+12.5 \% \mathrm{Na}_{2} \mathrm{SiO}_{3}+12.5 \% \mathrm{NaOH}$; i) $85 \% \mathrm{GrC}+15 \% \mathrm{PPP}+12.5 \% \mathrm{Na}_{2} \mathrm{SiO}_{3}+12.5 \% \mathrm{NaOH}$. 
showed that the microstructural properties of the samples corresponded with the results of their physical, mechanical, and thermal properties.

\section{CONCLUSIONS}

This study evaluated the thermal and mechanical properties of cellular ceramics prepared from granite dust mixed with ball clay (GrC) and plantain peel powder (PPP) using chemical aided sintering technology. The properties of the samples were influenced by the addition of varying amounts of plantain peels and varying amounts of the chemical reagents (sodium hydroxide and sodium silicate) used. The obtained results revealed water absorption of 19.5$41.7 \%$, bulk density of $1.39-1.86 \mathrm{~g} / \mathrm{cm}^{3}$, apparent porosity of 36.4-66.7\%, thermal conductivity of $0.09-0.62 \mathrm{~W} /(\mathrm{m} . \mathrm{K})$, and compressive strength of 0.9-18.4 MPa. The sample consisting of $95 \% \mathrm{GrC}, 5 \% \mathrm{PPP}$, and $10 \% \mathrm{NaOH}+10 \% \mathrm{Na}_{2} \mathrm{SiO}_{3}$, having a compressive strength of $18.4 \mathrm{MPa}$ and thermal conductivity of $0.32 \mathrm{~W} /(\mathrm{m} . \mathrm{K})$, was considered to have the optimum result in this study. Given the relatively low thermal conductivity and high compressive strength of the optimum sample of the prepared cellular ceramics, it can serve as a low-cost material for external wall insulation of buildings.

\section{ACKNOWLEDGMENTS}

The author thanks Dr. O.S. Adelabu of the Department of Industrial Design, University of Johannesburg, South Africa for his support in cash/kind and Dr. M.O. Bodunrin of the School of Chemical and Metallurgical Engineering, University of the Witwatersrand, Johannesburg, South Africa for the mineralogical and microstructural characterizations.

\section{REFERENCES}

[1] S. Mishra, J.A. Usmani, S. Varshney, Int. J. Eng. Res. Appl. 2, 5 (2012) 128.

[2] P.L. Simona, P. Spiru, I.V. Ion, Energy Procedia 128 (2017) 393.

[3] P.O. Akadiri, E.A. Chinyio, P.O. Olomolaiye, Buildings 2 (2012) 126.

[4] X. Meng, Y. Huang, Y. Cao, Y. Gao, C. Hou, L. Zhang, Q. Shen, Case Stud. Constr. Mater. 9 (2018) 1.

[5] R. Dylewski, J. Adamczyk, Build. Environ. 46 (2011) 2615.

[6] M.I. Emadi, in "Advances in environmental technology and biotechnology", Transilv. Un. Brasov, Romania (2014) 81.

[7] A.A. Alshorman, M. Alshorman, Int. J. Emerg. Trends Eng. Dev. 7, 6 (2017) 1.

[8] S.K. Saha, Procedia Eng. 14 (2011) 1913.

[9] Z. Tong, IOP Conf. Ser. Earth Environ. Sci. 100 (2017) 12141.

[10] S. Rashidi, J.A. Esfahani, N. Karimi, Renew. Sustain. Energy Rev. 91 (2018) 229.

[11] P. Colombo, Phil. Trans. R. Soc. A 364 (2006) 109.
[12] N.P. Stochero, E.G. de Moraes, A.P.N. de Oliveira, Mater. Res. 20, Suppl. 2 (2017) 549.

[13] F. Andreola, I. Lancellotti, R. Sergi, V. Cannillo, L. Barbieri, Materials 14, 1 (2021) 167.

[14] J. Alzukaimi, R. Jabrah, Cerâmica 66, 378 (2020) 208.

[15] M. Zhu, R. Ji, Z. Li, H. Wang, L. Liu, Z. Zhang, Constr. Build. Mater. 112 (2016) 398.

[16] M.M. Salman, N.S. Radhi, O.H. Sabr, H.T. Nhabih, Cerâmica 66, 378 (2020) 179.

[17] P.O. Odewole, D.O. Folorunso, Int. J. Eng. Manuf. 10, 5 (2020) 45.

[18] F. Andreola, A. Borghi, S. Pedrazzi, G. Allesina, P. Tartarini, I. Lancellotti, L. Barbieri, Materials 12 (2019) 3581.

[19] D. Eliche-Quesada, L. Pérez-Villarejo, F.J. IglesiasGodino, F.A. Corpas-Iglesias, Adv. Appl. Ceram. 110, 4 (2011) 225.

[20] A. Georgiev, A. Yoleva, S. Djambazov, J. Chem. Technol. Metall. 52, 5 (2017) 885.

[21] G. Görhana, O. Simsek, Constr. Build. Mater. 40 (2013) 390.

[22] J. Sutasa, A. Manab, L. Pitak, Procedia Eng. 32 (2012) 1061.

[23] N. Hedayat, Y. Du, J. Mater. Sci. Eng. 5, 4 (2016) 1.

[24] B.C. Echezona, K.P. Baiyeri, F.D. Aindigh, Tropicultura 29, 1 (2011) 14.

[25] S.O.S. Akinyemi, I.O. Aiyelaagbe, E. Akyeampong, Acta Hortic. 879 (2010) 211.

[26] S. Arcaro, B.G. Maia, M.T. Souza, F.R. Cesconeto, L. Granados, A.P.N. de Oliveira, Mater. Res. 19, 5 (2016) 1064. [27] M. Mouiya, A. Bouazizi, A. Abourriche, Y. ElKhessaimi, A. Benhammoua, Y. El-Hafiane, Y. Taha, M. Oumam, Y. Abouliatim, A. Smith, H. Hannache, Results Mater. 4 (2019) 100028.

[28] I.A. Cornejo, S. Ramalingam, J.S. Fish, I.E. Reimanis, Am. Ceram. Soc. Bull. 93, 6 (2014) 24.

[29] V.G. Levytskyi, O.M. Tolkach, ВІСНИК ЖДТУ 2, 80 (2017) 173.

[30] M. Lokeshwari, K.S. Jagadish, Procedia Environ. Sci. 35 (2016) 618

[31] G. Prokopski, V. Marchuk, A. Huts, Case Stud. Constr. Mater. 13 (2020) e00349.

[32] E. Saakyan, A. Arzumanyan, G. Galstyan, E3S Web Conf. 97 (2019) 2012.

[33] C.A. Ayedun, A.O. Oluwatobi, Bus. Manag. Dyn. 1, 4 (2011) 1.

[34] P.O. Odewole, I.B. Kashim, T.L. Akinbogun, in Proc. $1^{\text {st }}$ Visual Commun. Design Conf., T.L. Akinbogun, I.B. Kashim, E.L. Etsename, O.F. Kayode, O.S. Adelabu (Eds.), Fed. Un. Technol., Akure (2019) 201.

[35] ASTM C20-00, "Standard test methods for apparent porosity, water absorption, apparent specific gravity, and bulk density of burned refractory brick and shapes by boiling water", ASTM Int., West Conshohocken (2010).

[36] ASTM C240-97, "Standard test methods of testing cellular glass insulation block", ASTM Int., West Conshohocken (1998). 
[37] F.O. Aramide, J. Miner. Mater. Charact. Eng. 11 (2012) 970.

[38] E.O. Obidiegwu, D.E. Esezobor, J.O. Agunsoye, G.I. Lawal, J. Miner. Mater. Charact. Eng. 3 (2015) 458.

[39] C.-H. Ho, H.-M. Lo, K.-L. Lin, J.-Y. Lan, Environ. Prog. Sustain. Energy 38, 2 (2019) 321.

[40] S.A. Zaidan, A.F. Hamood, S.N. Ibrahim, Eng. Technol. J. 34, 4 Part B (2016) 610.
[41] M. Zhu, R. Ji, Z. Li, H. Wang, L. Liu, Z. Zhang, Constr. Build. Mater. 112 (2016) 398.

[42] J.G. Ten, M.J. Orts, S.G. Silva, Ceram. Int. 36 (2010) 1951.

[43] J.P. Wu, A.R. Boccaccini, P.D. Lee, M.J. Kershaw, R.D. Rawlings, Adv. Appl. Ceram. 105, 1 (2006) 32.

(Rec. 04/01/2021, Rev. 31/03/2021, 26/05/2021, Ac. $30 / 05 / 2021)$ 